\begin{tabular}{|l|l|}
\hline & \\
\hline
\end{tabular}

SEÇÃO: PRODUÇÃO LIVRE

\title{
A terra plana
}

The Flat Land

\section{José D'Assunção \\ Barros $^{1}$ \\ orcid.org/0000-0002-3974-0263 joseassun57@gmail.com}

Recebido em: 18/11/2020. Aprovado em: 04/11/2021. Publicado em: 28/12/2021.
Descobriram que a Terra é plana

e as pessoas chatas.

Definiram, de vez por todas,

que a humanidade insana

não vale um dobrão de prata

Ah, deuses da virgem mata!

A Gangue dos Decibéis

com dois toscos pares de régua

redesenhou um universo

andrajoso e deselegante

A Terra, tão coitada como arrogante,

tornou-se uma prisão de gelo

que olha para o restante espaço

à maneira de um estranho prato

de borda dura como a lei

O Sol, outrora um rei,

de sua ideologia de gênero

foi pomposamente destronado

e agora corre, corre, corre

humilde e desesperado

Mero pimpolho, de fogo endiabrado,

tem agora o tamanho da Lua

e ambos são bolinhas simplórias

que correm uma atrás da outra

como cão e cadela em cio

\section{(c) (1)}


E, falando em cão, por desafio, era tudo conspiração

desde as mais das priscas eras

desde as sociedades secretas

que se escondem sob o chão

Com a terra plana, de roldão,

toda ciência se dissolveu

As matemáticas se danaram,

a gravidade saiu flutuando

como bolhas (ou moedas) de sabão

\section{José D'Assunção Barros}

Doutor em História pela Universidade Federal Fluminense (UFF), em Niterói, RJ, Brasil. Professor Associado da Universidade Federal Rural do Rio de Janeiro, nos cursos de Graduação e Pós-Graduação em História, em Nova Iguaçu, RJ, Brasil. Professor Permanente do Programa de Pós-Graduação em História Comparada da Universidade Federal do Rio de Janeiro (UFRJ), no Rio de Janeiro, RJ, Brasil.

Os textos deste artigo foram revisados por Poá Comunicação e submetidos para validação do(s) autor(es) antes da publicação. 